\title{
ANURANS OF JUIZ DE FORA MUNICIPALITY, ZONA DA MATA OF MINAS GERAIS STATE, BRAZIL
}

\author{
Matheus de Oliveira Neves ${ }^{*}$, Vanessa Gonçalves Ferreira ${ }^{2}$, Emanuel Masiero da Fonseca ${ }^{3}$, \\ Karoline Ceron ${ }^{1}$, Celso Henrique Varela-Rios ${ }^{4} \&$ Rose Marie Hoffmann de Carvalho ${ }^{4}$
}

\begin{abstract}
${ }^{1}$ Universidade Federal de Mato Grosso do Sul (UFMS), Instituto de Biociências, Programa de Pós Graduação em Ecologia e Conservação. Cidade Universitária, Campo Grande, MS, Brasil. CEP: 79070-900

${ }^{2}$ Universidade Federal de Mato Grosso do Sul (UFMS), Instituto de Biociências, Programa de Pós Graduação em Biologia Animal. Cidade Universitária, Campo Grande, MS, Brasil. CEP: 79070-900

${ }^{3}$ Universidade Federal do Rio Grande do Norte (UFRN), Departamento de Ecologia, Programa de Pós Graduação em Ecologia. Lagoa Nova, Natal, RN, Brasil. CEP: 59072-970

${ }^{4}$ Universidade Federal de Juiz de Fora (UFJF), Instituto de Ciências Biológicas, Laboratório de Herpetologia/Anfíbios, Departamento de Zoologia, Campus Universitário, São Pedro, Juiz de Fora, MG, Brasil. CEP: 36036-900

E-mails: nevesmo@yahoo.com.br, vanessagf.09@gmail.com, emanuelmfonseca@gmail.com, adenomera@gmail.com, celsohvrios@gmail.com,rosemarie.hoffmann@ufjf.edu.br
\end{abstract}

\begin{abstract}
The Atlantic Forest is considered a biodiversity hotspot due to a large concentration of endemic species and an associated high vulnerability to human disturbance. The Serra da Mantiqueira in southeastern Brazil stands out as an important region to anurofauna composition, presenting endemic and threatened species. Conversely, the species composition of the amphibian communities of several areas in the Serra da Mantiqueira is still unknown. Filling these knowledge gaps is a fundamental task to protect these areas and the associated biota. Herein, we provide a list of anurans for the Juiz de Fora municipality, Minas Gerais state, in southeastern Brazil. The species list is based on museum records of specimens deposited in the Coleção de Anfíbios da Universidade Federal de Juiz de Fora (CAUFJF). In addition, other records were derived from fieldwork on five urban fragments. We recorded 46 species belonging to 11 families and 22 genera. Of that total, thirty-eight species $(83 \%)$ can be found in urban fragments. No species are on lists of endangered species, although Chiasmocleis mantiqueira, Ischnocnema verrucosa, Myersiella microps, Phasmahyla cochranae, and Zachaenus carvalhoi are considered data deficient. Adelophryne meridionalis is so far considered endemic to the Parque Municipal Lajinha, in Juiz de Fora. The municipality also showed high species richness when compared with other regions in the Serra da Mantiqueira. The present study demonstrates that even small and disturbed areas harbor important, endemic species and may help to fill the knowledge gaps about diversity in the state of Minas Gerais.
\end{abstract}

Keywords: amphibians; Atlantic Forest; Serra da Mantiqueira; species inventory; species richness.

\section{INTRODUCTION}

The Brazilian Atlantic Forest (AF) originally covered about $1,500,000 \mathrm{~km}^{2}$ of the eastern coast of South America, extending from northeastern to southern Brazil (Ribeiro et al. 2009). Historically, the AF domain has been deeply impacted by agriculture, cattle ranching, timber extraction, and urban expansion (Morellato \& Haddad 2000), with only about $11.4 \%-16 \%$ of its original extension remaining (SOSMA 2017). The remarkable high levels of species richness and endemism have often been used to describe AF biodiversity (Myers et al. 2000, Silva et al. 2004, Haddad et al. 2013). The AF regions occupy the large proportion of the Brazilian coastal region. The AF highlands are considered biodiversity hotspots, with a large concentration of endemic species and an associated high vulnerability to human disturbance (Myers et al. 2000).

Amphibians are a prominent group of vertebrates, with more than 7,690 described species (Frost 2017) and higher species richness found in the tropics (Pyron \& Wiens 2013). Currently, 1,080 species are registered in Brazil (Segalla et al. 2016) and approximately $50 \%$ of them occur in the AF (Haddad et al. 2013). Most of this high diversity occurs in areas of medium elevation (about $600 \mathrm{~m}$ a.s.1.) in the $\mathrm{AF}$ (Siqueira \& Rocha 2013), although some studies suggest that high elevation areas (about $1000 \mathrm{~m}$ a.s.1.) in mountainous regions of southeastern Brazil reach higher levels of endemism (e.g., Serra do Mar and 
Serra da Mantiqueira) (Cruz \& Feio 2007). These highlands promote genetic isolation between populations, favoring allopatric speciation (Firkowski et al. 2016). The Mantiqueira highland complex (Serra da Mantiqueira here on) stands out as an important region to anurofauna composition, presenting endemic and threatened species (Moura et al. 2012, Vasconcelos et al. 2014, Barata et al. 2016). Large areas in the Serra da Mantiqueira still need inventories of amphibians and many localities have been subsampled (Silvano \& Segalla 2005). Further studies are necessary to show patterns of diversity and endemism of these animals (Moura et al. 2012).

Despite that, knowledge about the composition of amphibian communities in the Serra da Mantiqueira has increased in the last decade, which is a consequence of valuable studies in this region (e.g., Cruz et al. 2009, Almeida et al. 2011, Gomides \& Sousa 2012, Moura et al. 2012). This knowledge is still incipient and fragmented, because most studies have focused on high elevation regions $(>1,000 \mathrm{~m}$ a.s.1.) (Nascimento et al. 2009). In addition, extensive areas remain subsampled, and the information generated about species distribution in these areas is fundamental for the management and conservation planning in the AF (Silveira et al. 2010, Verdade et al. 2012). Moreover, other areas such as biogeography, ecology, and evolution will benefit from this information (e.g., Costa et al. 2007, Rosauer et al. 2009, Vasconcelos et al. 2014, Barata et al. 2016).

Herein, we provide the first list of anurans for the Juiz de Fora municipality, Minas Gerais state, in southeastern Brazil. The aim of this study is to contribute to the gap in knowledge about amphibian diversity of the Serra da Mantiqueira.

\section{MATERIAL AND METHODS}

\section{Study site}

Juiz de Fora $\left(21^{\circ} 45^{\prime} 44.73^{\prime \prime} \mathrm{S}, 4^{\circ} 20^{\prime} 36.24^{\prime \prime} \mathrm{W}\right.$, Datum WGS84; Figure 1) is one of the most populous municipalities in the state of Minas Gerais, southeastern Brazil. Juiz de Fora is located at the Serra da Mantiqueira, extending over $1,424 \mathrm{~km}^{2}$. It is drained by the middle Paraibuna River, and the elevation ranges from 467 to 1,104 m a.s.l. (Pifano et al. 2007). Although originally covered by the AF vegetation, most of the landscape is now used for agriculture. According to the Köppen's classification, the climate is Cwa type (Alvares et al. 2013) with hot summers and an annual average temperature around $22.5^{\circ} \mathrm{C}$ and an average annual rainfall of 1,470 $\mathrm{mm}$ (Borges 2006).

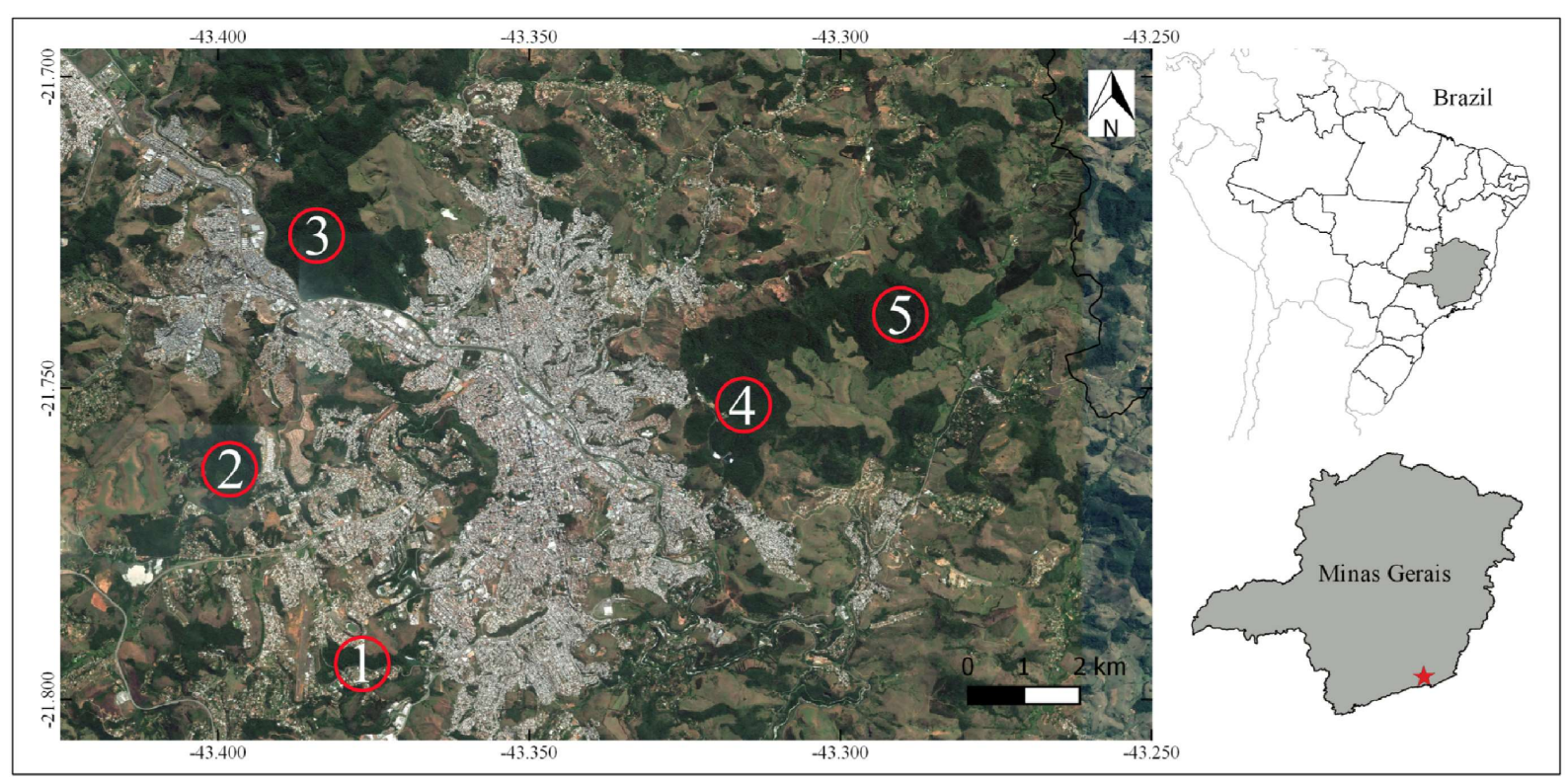

Figure 1. Geographic location of Juiz de Fora municipality (red star) in the Minas Gerais state, southeastern Brazil. Numbers indicate urban fragments: (1) Parque Natural Municipal da Lajinha, (2) Reserva Biológica Municipal de Santa Cândida, (3) Área de Proteção Ambiental Mata do Krambeck/Jardim Botânico da UFJF, (4) Reserva Biológica Municipal do Poço D'Anta, and (5) Fazenda Floresta. 


\section{Data collection}

To generate the anurans species list, we analyzed the specimens deposited in the Coleção de Anfíbios da Universidade Federal de Juiz de Fora (CAUFJF; Appendix 1). This regional collection has specimens collected in Juiz de Fora municipality from 1970, with a total of 1,717 specimens deposited until 2015. Most individuals were captured during research projects conducted by students of the Laboratório de Anfíbios at the Universidade Federal de Juiz de Fora. All specimens were carefully checked to confirm their identification by experts to avoid misleading information. Moreover, the checklist was complemented by fieldwork from 2006 to 2011 in five urban fragments. Three lines of fence (100 meters each) interspersed with a pitfall and funnel trap arranged every 10 meters were allocated in five urban fragments of Juiz de Fora municipality: (1) Parque Natural Municipal da Lajinha (14 months), (2) Reserva Biológica Municipal de Santa Cândida (eight months), (3) Área de Proteção Ambiental Mata do Krambeck/Jardim Botânico da UFJF (six months), (4) Reserva Biológica Municipal do Poço D'Anta (eight months), and (5) Fazenda Floresta (eight months) (Figure 1). In total, 1500 meters of fence with 90 pitfall traps and 75 pairs of funnels were allocated. We also performed sporadic active searches to collect arboreal species, which were not covered using passive method (pitfall and funnel traps) (Collection License ICMBio 22961-1 / 17746-1).
We checked the conservation status of each species recorded according to the list of threatened species in the state of Minas Gerais (COPAM 2010), the Brazilian list of threatened species (ICMBio 2016), and the red list of threatened species of the International Union for Conservation of Nature and Natural Resources (IUCN 2017).

\section{RESULTS}

We recognized 46 species, distributed in 11 families (Table 1): Brachycephalidae ( $\mathrm{n}=7$, Figure 2ac), Bufonidae ( $\mathrm{n}=1$, Figure 2d), Craugastoridae ( $\mathrm{n}=$ 1), Cycloramphidae $(\mathrm{n}=2$, Figure $2 \mathrm{e})$, Eleutherodactylidae $(n=1$, Figure $2 f)$, Hylidae $(n=20$, Figure $2 \mathrm{~g}-\mathrm{h}$ and $3 \mathrm{a}-\mathrm{c})$, Hylodidae $(\mathrm{n}=1$, Figure $3 \mathrm{~d})$, Leptodactylidae ( $n=7$, Figure 3e), Microhylidae $(n=3$, Figure 3f-g), Odontophrynidae ( $\mathrm{n}=2$, Figure $3 \mathrm{~h}$ ), and Ranidae $(\mathrm{n}=1)$. One species (Lithobates catesbeianus) is considered exotic and $53.4 \%$ of species are endemic to the AF. Hylidae showed the greatest number of species $(43.5 \%)$, followed by Leptodactylidae (15.2\%). Three species, Adelophryne meridionalis, Ischnocnema verrucosa, and Scinax fuscovarius, were described based on specimens collected in Juiz de Fora (type-locality). Thirty-eight out of the 46 species were registered in urban fragments. The higher species richness $(n=26)$ was recorded in the Area de Proteção Ambiental Mata do Krambeck.

Table 1. Anurans species recorded in Juiz de Fora municipality, Minas Gerais state, Brazil. Urban fragments were amphibian species were recorded: (1) Parque Natural Municipal da Lajinha, (2) Reserva Biológica Municipal de Santa Cândida, (3) Área de Proteção Ambiental Mata do Krambeck/Jardim Botânico da UFJF, (4) Reserva Biológica Municipal do Poço D'Anta, and (5) Fazenda Floresta. *Endemic species of the Atlantic Forest according to Haddad et al. (2013). **Records derived only from CAUFJF.

\begin{tabular}{lc}
\hline Family/ Species & Urban fragments \\
\hline Brachycephalidae & \\
Ischnocnema juipoca (Sazima \& Cardoso, 1978)* & $1,2,3,4,5$ \\
Ischnocnema nasuta (A. Lutz, 1925)* & 1,3 \\
Ischnocnema verrucosa (Reinhardt \& Lütken, 1862)* & $1,2,3,4,5$ \\
Ischnocnema aff. guentheri & $1,2,3,4,5$ \\
Ischnocnema gr. lactea & $* *$ \\
Ischnocnema gr. parva 1 & $1,2,3,4$ \\
Ischnocnema gr. parva 2 & 1 \\
\hline
\end{tabular}


... continued

\begin{tabular}{|c|c|}
\hline Family/ Species & Urban fragments \\
\hline \multicolumn{2}{|l|}{ Bufonidae } \\
\hline Rhinella gr. crucifer & $1,2,3,4,5$ \\
\hline \multicolumn{2}{|l|}{ Craugastoridae } \\
\hline Haddadus binotatus (Spix, 1824)* & $1,2,3,4,5$ \\
\hline \multicolumn{2}{|l|}{ Cycloramphidae } \\
\hline Thoropa miliaris (Spix, 1824)* & $1,3,5$ \\
\hline Zachaenus carvalhoi Izecksohn, 1983"1982"* & $1,4,5$ \\
\hline \multicolumn{2}{|l|}{ Eleutherodactylidae } \\
\hline Adelophryne meridionalis Santana, Fonseca, Neves \& Carvalho, 2012* & 1,4 \\
\hline \multicolumn{2}{|l|}{ Hylidae } \\
\hline Bokermannohyla gr. circumdata & 1 \\
\hline Dendropsophus branneri (Cochran, 1948) & 3 \\
\hline Dendropsophus decipiens (A. Lutz, 1925) & 3 \\
\hline Dendropsophus elegans (Wied-Neuwied, 1824)* & 3 \\
\hline Dendropsophus minutus (Peters, 1872) & 2,3 \\
\hline Hypsiboas albomarginatus (Spix, 1824)* & 3 \\
\hline Hypsiboas albopunctatus (Spix, 1824) & $* *$ \\
\hline Hypsiboas faber (Wied-Neuwied, 1821)* & 2,3 \\
\hline Hypsiboas pardalis (Spix, 1824)* & 1,3 \\
\hline Hypsiboas polytaenius (Cope, 1870$)^{*}$ & $2,4,5$ \\
\hline Hypsiboas semilineatus (Spix, 1824)* & 3,4 \\
\hline Phasmahyla cochranae (Bokermann, 1966)* & 5 \\
\hline Phyllomedusa burmeisteri Boulenger, 1882* & $1,3,5$ \\
\hline Scinax crospedospilus (A. Lutz, 1925)* & 3 \\
\hline Scinax eurydice (Bokermann, 1968)* & 1,3 \\
\hline Scinax fuscovarius (A. Lutz, 1925) & $* *$ \\
\hline Scinax hayii (Barbour, 1909)* & $* *$ \\
\hline Scinax luizotavioi (Caramaschi \& Kisteumacher, 1989)* & 1,3 \\
\hline Scinax $x$-signatus (Spix, 1824) & $* *$ \\
\hline Scinax gr. catharinae & 1,3 \\
\hline \multicolumn{2}{|l|}{ Hylodidae } \\
\hline Hylodes lateristrigatus (Baumann, 1912)* & 1,5 \\
\hline \multicolumn{2}{|l|}{ Leptodactylidae } \\
\hline Adenomera marmorata (Steindachner, 1867)* & 1,3 \\
\hline Leptodactylus furnarius Sazima \& Bokermann, 1978 & 1 \\
\hline Leptodactylus fuscus (Schneider, 1799) & 3 \\
\hline Leptodactylus labyrinthicus (Spix, 1824) & 1 \\
\hline Leptodactylus latrans (Steffen, 1815) & 3 \\
\hline
\end{tabular}


... continued

\begin{tabular}{lc}
\hline Family/ Species & Urban fragments \\
\hline Leptodactylidae & $1,2,3,5$ \\
Physalaemus cuvieri Fitzinger, 1826 & $* *$ \\
Physalaemus signifer (Girard, 1853)* & \\
Microhylidae & 1 \\
Chiasmocleis mantiqueira Cruz, Feio \& Cassini, 2007* & $* *$ \\
Elachistocleis cesarii (Miranda-Ribeiro, 1920) & $1,2,4,5$ \\
Myersiella microps (Duméril \& Bibron, 1841)* & \\
Odontophrynidae & $* *$ \\
Odontophrynus americanus (Duméril \& Bibron, 1841) & $1,2,3,4,5$ \\
Proceratophrys boiei (Wied-Neuwied, 1825)* & \\
Ranidae & 2 \\
Lithobates catesbeianus (Shaw, 1802) & \\
\hline
\end{tabular}

None of the species identified in this study present any degree of threat from lists of endangered species. However, some species are classified as Data Deficient (DD), such as Zachaenus carvalhoi, Phasmahyla cochranae, and Myersiella microps in Minas Gerais state, as well as I. verrucosa, Z. carvalhoi, and Chiasmocleis mantiqueira at global level.

\section{DISCUSSION}

The number of species recorded in this study were similar to those found in nearby areas in the Serra da Mantiqueira, despite the methodological differences, such as in the Serra Negra da Mantiqueira (48 species; Neves et al. 2017), in the Parque Estadual da Serra do Brigadeiro (47 species, Moura et al. 2012) and the Parque Estadual do Ibitipoca (36 species; Cruz et al. 2009). Also, they were higher than that found in the Serra do Relógio (17 species; Gomides \& Sousa 2012). Most of those areas show a relatively high number of species, which is one of the prominent characteristic of highlands in the AF (Cruz \& Feio 2007). Differences in species richness among these areas might be related to methodology, sampling effort or to the degree of the conservation status of the areas.

In this study, urban fragments of the Juiz de Fora municipality housed a considerable number of anuran species present in the city (83\%). The importance of cities for biodiversity conservation grows with the increase of urbanization (Kowarik 2011). Landscapes where cities are inserted usually are highly fragmented and composed for a mosaic of land-uses types that vary from fragments of native forests to buildings. Urban fragments are repositories of current and future biodiversity, offering refuge for numerous animal species, but also are generally under direct control by humans (Faeth et al. 2011, Souza-Campana et al. 2016). This is the case of Adelophryne meridionalis, a diminutive species that currently is only known from the Parque Natural Municipal da Lajinha (type locality), in Juiz de Fora (ca. 880 m a.s.1.) (Santana et al. 2012).

Hylodes lateristrigatus has its distribution in southeastern Brazil, occurring in few localities in Espírito Santo, Rio de Janeiro, and Minas Gerais states (Salles et al. 2012, Moura et al. 2012, Vrcibradic et al. 2014). In the State of Minas Gerais, the species is only known to occur in the Parque Estadual da Serra do Brigadeiro (Moura et al. 2012). In this study, we provided a second record for this species in the state.

Belonging to a problematic taxonomic group, Ischnocnema sp. (aff. guentheri) presents morphological characteristics similar to Ischnocnema guentheri (Steindachner, 1864), which is considered endemic of the Parque Nacional da Floresta da Tijuca, in the State of Rio de Janeiro (Gehara et al. 2013). In a recent molecular study, Gehara et al. (2013) identified a probable new and cryptic species (candidate species 3 ) in the Juiz de Fora 
municipality, as well as in the Serra do Itatiaia, both located within the Serra da Mantiqueira. Cryptic species (i.e., two or more distinct species that are classified as a single species) are numerous to amphibians, and usually appears to be a single, nominal widespread species that may be comprised of morphologically similar but geographically restricted species (Bickford et al. 2007). The two species of this study belong to Ischnocnema parva group and $I$.
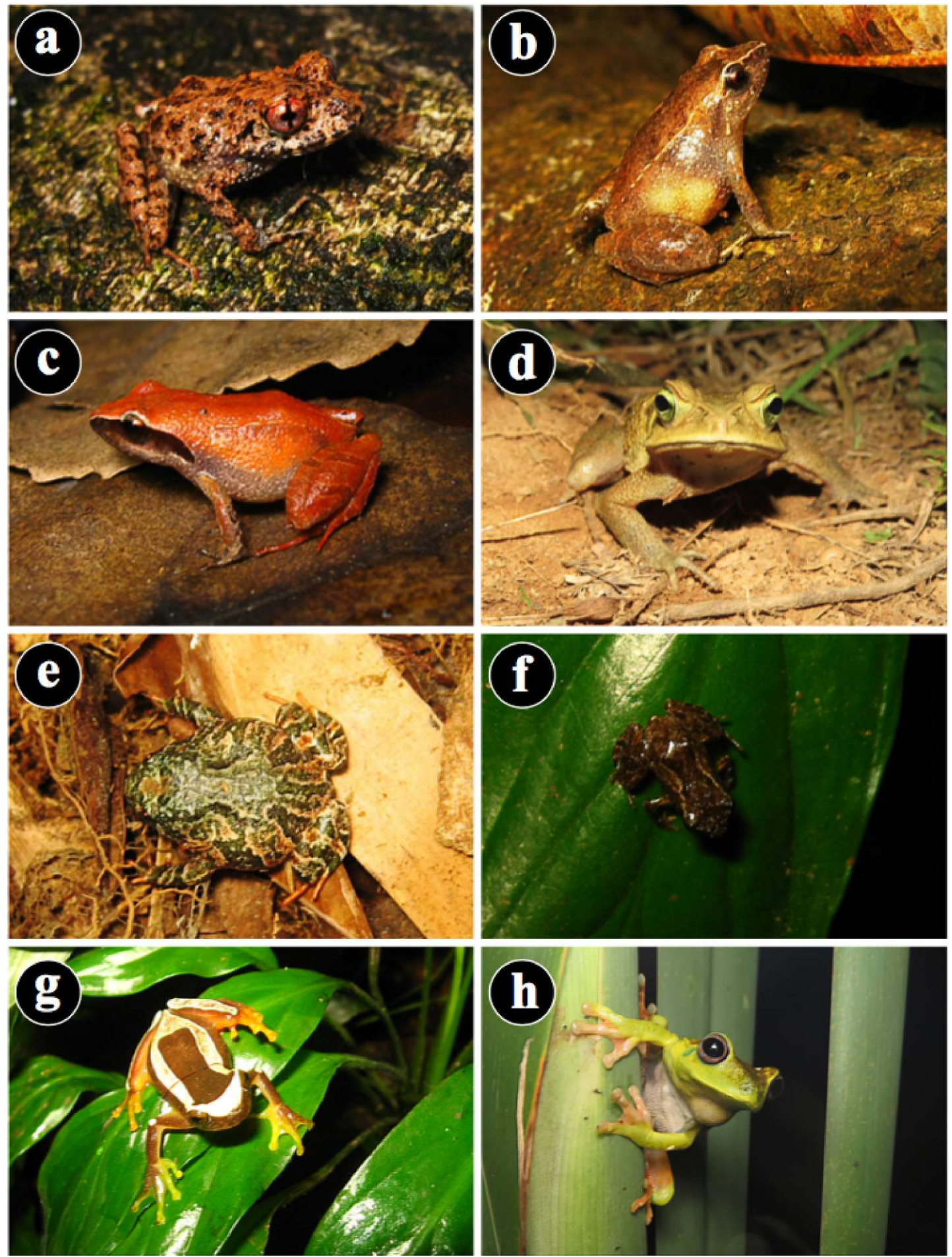

Figure 2. Anuran amphibians from Juiz de Fora, Zona da Mata of Minas Gerais state, Brazil: Family Brachycephalidae: (a) Ischnocnema verrucosa, (b) Ischnocnema gr. parva 1, (c) Ischnocnema gr. parva 2; Family Bufonidae: (d) Rhinella gr. crucifer; Family Cycloramphidae: (e) Zachaenus carvalhoi; Family Eleutherodactylidae: (f) Adelophryne meridionalis; and Family Hylidae: (g) Dendropsophus elegans; (h) Hypsiboas albomarginatus. 
lactea group that are taxonomically complex and difficult to identify. Recently, Gehara et al. (2017) demonstrate that I. parva comprises six species and the nominal I. parva is the lineage found at the type-locality in State of Rio de Janeiro. The specimen attributed to $I$. lactea from CAUFJF did not show the necessary characters for a correct diagnosis due to the long time since it was collected.
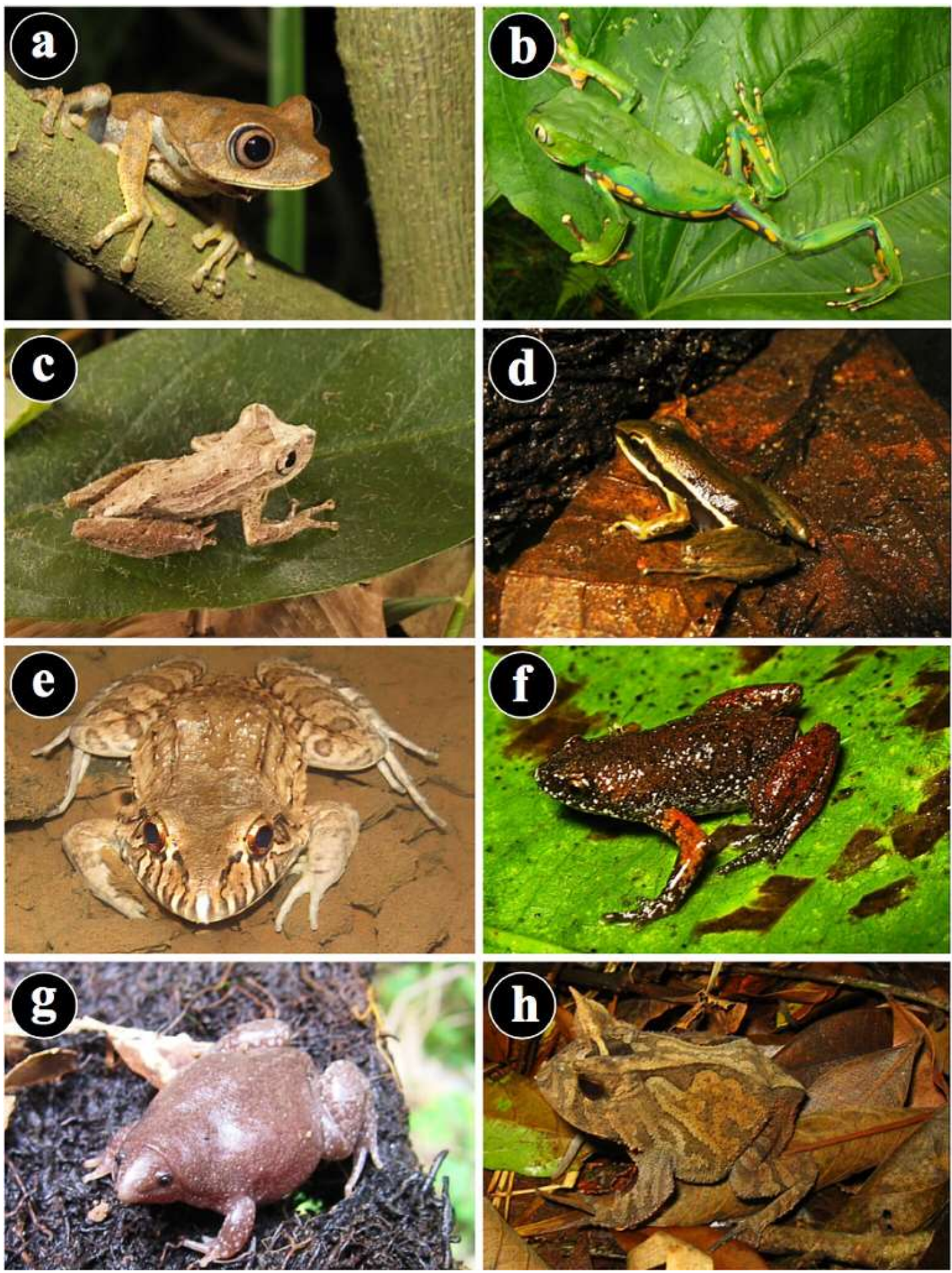

Figure 3. Anuran amphibians from Juiz de Fora, Zona da Mata of Minas Gerais state, Brazil: Family Hylidae: (a) Hypsiboas semilineatus, (b) Phyllomedusa burmeisteri, (c) Scinax luizotavioi; Family Hylodidae: (d) Hylodes lateristrigatus; Family Leptodactylidae:(e) Leptodactylus labyrinthicus; Microhylidae: (f) Chiasmocleis mantiqueira, (g) Myersiella microps; and Family Odontophrynidae: (h) Proceratophrys boiei. Credit: Flávia Mól Lanna (c). 
In the Serra da Mantiqueira complex, Rhinella gr. crucifer species are identified as $R$. crucifer (Parque Nacional do Itatiaia by IBDF 1982), R. pombali (Parque Estadual da Serra do Brigadeiro by Moura et al. 2012) or $R$. ornata (Serra Negra da Mantiqueira by Neves et $a l$. 2017). However, in Juiz de Fora, the species identified as Rhinella gr. crucifer presents features of both $R$. crucifer and $R$. ornata. Juiz de Fora is close to the extreme of the distribution of these two species and hybridization might be a common occurrence, which would make it difficult to distinguish these species (see map at Thomé et al. 2010). Moreover, Thomé et al. (2010) put in doubt the taxonomic status of R. pombali from a phylogenetic point of view. Given all these arguments, we prefer keep the species collected in Juiz de Fora under Rhinella gr. crucifer.

Lithobates catesbeianus is a North American species introduced in many countries around the world (Lowe et al. 2000, Lever 2003). This species stands out for its high likelihood of becoming an invasive species in environments where it is introduced (Kats \& Ferrer 2003, Ficetola et al. 2007). In fact, this species is considered one of the 100 worst invasive species in the world (Lowe et al. 2000). It is already a widespread species in Brazil, where its invasion began in the 1930's due to the release from aquaculture farms (Both et al. 2011, Fontanello \& Ferreira 2016). In Juiz de Fora, this species occurs only at Reserva Biológica Municipal de Santa Cândida. However, there is no information to date about its actual impacts on the native anurofauna in Juiz de Fora, although its potential impacts on Brazilian anurans are widely known and alarming (Lowe et al. 2000, Boelter et al. 2012, Both \& Grant 2012, Silva et al. 2016).

Aplastodiscus cavicola had its confirmed occurrence for the Área de Proteção Ambiental Mata do Krambeck through the registration of its advertisement call. However, as the specimen was recorded vocalizing buried, it was not possible to find it (no voucher). Thus, we prefer not to incorporate it into Juiz de Fora species list, although Cruz \& Peixoto (1985) have registered the species for the municipality.

Faunal inventories are essential to the understanding of biodiversity and consequently for conservation planning strategies (Haddad 1998, Provete 2015). Although none of the species recorded in this study are considered endangered, Juiz de Fora harbors some poorly known species, such as Ischnocnema verrucosa, Zachaenus carvalhoi, Adelophryne meridionalis, Phasmahyla cochranae, Myersiella microps, and Chiasmocleis mantiqueira. There is a lack of basic information on these species (e.g., population size and natural history), preventing the assessment of their threatened status. Many times, studies with poorly known species are hampered due to the restricted distribution of the species and/or difficulty to access the area where the species occur, or even due to the species secretive behavior (Morais et al. 2013). We further highlight the need of more studies dedicated to these species to better understand their actual conservation status.

The lack of data on anurans along with the importance of these species and the region where they occur for conservation emphasizes the importance of studies for the understanding and preservation of the fauna of Minas Gerais. There is also the need for long-term studies of the assemblages and populations to assess possible declines and threats to amphibians of the state. The results generated here are of most importance for future conservation strategies and species assessments to protect and maintain this biodiversity over time. Still, the present study demonstrates that even small and disturbed areas harbor important, threatened species, and may help to fill the knowledge gaps about the diversity in the state of Minas Gerais.

\section{ACKNOWLEDGEMENTS}

We thank all students of the Universidade Federal de Juiz de Fora who contributed to the collection of specimens. Leandro Alves da Silva, Vinícius São-Pedro and Sarah Mângia for reviewing the manuscript. Emanuel Teixeira da Silva for helping in the identification of the specimens.

\section{REFERENCES}

Almeida, A. P., Gasparini, J. L, \& Peloso, P. L. V. 2011. Frogs of Espírito Santo, southeastern Brazil - the need for looking at the 'coldspots'. Check List, 7(4), 542-560.

Alvares, C. A., Stape, J. L., Sentelhas, P. C., de Moraes, G., Leonardo, J., Sparovek, G. 2013. Köppen's climate classification map for Brazil. Meteorologische Zeitschrift, 22(6), 711-728.

Barata, I. M., Uhlig, V. M., Silva, G. H., Ferreira, G. B. 2016. Downscaling the gap: protected areas, scientific knowledge 
and the conservation of amphibian species in Minas Gerais, southeastern Brazil. South American Journal of Herpetology, 11(1), 34-45. DOI: 10.2994/SAJH-D-16-00006.1

Bickford, D., Lohman, D. J., Sodhi, N. S., Ng, P. K. L., Meier, R., Winker, K., Das, I. 2007. Cryptic species as a window on diversity and conservation. Trends in Ecology \& Evolution, 22(3), 148-155. DOI: 10.1016/j.tree.2006.11.004

Boelter, R. A., Kaefer, I. L., Both, C., Cechin, S. 2012. Invasive bullfrogs as predators in a Neotropical assemblage: What frog species do they eat? Animal Biology, 62(4), 397-408. DOI: $10.1163 / 157075612$ X634111

Borges, V. V. 2006. Laboratório de Climatologia e Análise Ambiental. Departamento de Geociências da Universidade Federal de Juiz de Fora. p. 87

Both, C., \& Grant, T. 2012. Biological invasions and the acoustic niche: the effect of bullfrog calls on the acoustic signals of white-banded tree frogs. Biology Letters, 8(5), 714-716. DOI: 10.1098/rsbl.2012.0412

Both, C., Lingnau, R., Santos-Jr, A., Madalozzo, B., Lima, L. P., Grant, T. 2011. Widespread occurrence of the American Bullfrog, Lithobates catesbeianus (Shaw, 1802) (Anura: Ranidae), in Brazil. South American Journal of Herpetology, 6(2), 127-134. DOI: 10.2994/057.006.0203

Costa, G. C., Nogueira, C., Machado, R. B., Colli, G. R. 2007. Squamate richness in the Brazilian Cerrado and its environmentalclimatic associations. Diversity and Distributions, 13, 714724. DOI: 10.1111/j.1472-4642.2007.00369.x

Conselho de Política Ambiental - COPAM. 2010. Deliberação Normativa COPAM n ${ }^{\circ} 147$, de 30 de abril de 2010. Aprova a Lista de Espécies Ameaçadas de Extinção da Fauna do Estado de Minas Gerais. Diário do Executivo do Estado de Minas Gerais, Belo Horizonte, 04 maio 2010.

Cruz, C. A. G., \& Peixoto, O. L. 1985. Espécies verdes de Hyla: o complexo "albosignata" (Amphibia, Anura, Hylidae). Arquivos da Universidade Federal Rural do Rio de Janeiro, 71, 31-47.

Cruz, C. A. G., \& Feio, R. N. 2007. Endemismos em anfíbios em áreas de altitude na Mata Atlântica no sudeste do Brasil. In: L. B. Nascimento \& M. E. Oliveira (Eds.), Herpetologia no Brasil II. Sociedade Brasileira de Herpetologia. pp. 11-126. Belo Horizonte: Sociedade Brasileira de Herpetologia.

Cruz, C. A. G., Feio, R. N., \& Caramaschi, U. 2009. Anfíbios do Ibitipoca. 1st ed. Bicho do Mato Editora: p. 132.

Faeth, S. H., Bang, C. \& Saari, S. 2011. Urban biodiversity: patterns and mechanisms. Annals of the New York Academy of Sciences, 1223, 69-81. DOI: $10.1111 / j .1749-6632.2010 .05925 . x$

Ficetola, G. F., Thuiller, W., \& Miaud, C. 2007. Prediction and validation of the potential global distribution of a problematic alien invasive species - the American bullfrog. Diversity and Distribution, 13, 476-485. DOI: $10.1111 / \mathrm{j} .1472$ 4642.2007.00377.x

Firkowski, C. R., Bornschein, M. R., Ribeiro, L. F., Pie, M. R. 2016. Species delimitation, phylogeny and evolutionary demography of co-distributed, montane frogs the southern Brazilian Atlantic Forest. Molecular Phylogenetics and Evolution, 100, 345-360. DOI: 10.1016/j.ympev.2016.04.023 Fontanello, D., \& Ferreira, C. M. 2016. Histórico da ranicultura nacional. Retrieved October 24, 2016 from http:// www.aquicultura.br/

Frost, D. 2017. Amphibian Species of the World: an Online Reference. Version 6.0. Retrieved February 03, 2017 from http://research.amnh.org/herpetology/amphibia/index.html

Gehara, M., Canedo, C., Haddad, C. F. B., Vences, M. 2013. From widespread to microendemic: molecular and acoustic analyses show that Ischnocnema guentheri (Amphibia: Brachycephalidae) is endemic to Rio de Janeiro, Brazil. Conservation Genetics, 14, 973-982. DOI: 10.1007/s10592013-0488-5

Gehara, M., Barth, A., de Oliveira, E. F., Costa, M. A., Haddad, C. F. B., Vences, M. 2017. Model-based analyses reveal insular population diversification and cryptic frog species in the Ischnocnema parva complex in the Atlantic forest of Brazil. Molecular Phylogenetics and Evolution, 112, 68-78. DOI: 10.1016/j.ympev.2017.04.007

Gomides, S. C. \& Sousa, B. M. 2012. Levantamento preliminar da herpetofauna da Serra do Relógio, Minas Gerais, sudeste do Brasil. Revista Brasileira de Zoociências, 14(1, 2, 3), 45-56.

Haddad, C. F. B. 1998. Biodiversidade dos Anfíbios no Estado de São Paulo. In: R. M. C. Castro (Ed.), Biodiversidade do Estado de São Paulo, Brasil: síntese do conhecimento ao final do Século XX. pp. 15-26. FAPESP.

Haddad, C. F. B., Toledo, L. F., Prado, C. P. A., Loebmann, D., Gasparini, J. L., Sazima, I. 2013. Guia dos Anfíbios da Mata Atlântica: diversidade e biologia. 1st ed. São Paulo, SP: Anolis Books: p. 543.

Instituto Brasileiro de Desenvolvimento Florestal, Fundação Brasileira para Conservação da Natureza - IBDF. 1982. Plano de manejo: Parque Nacional do Itatiaia. IBDF, FBCN, Brasília, Brazil, $207 \mathrm{p}$.

Instituto Chico Mendes de Conservação à Biodiversidade ICMBio. 2016. Listas nacionais de espécies ameaçadas de extinção. ICMBio, Brasília, Distrito Federal.

International Union for Conservation of Nature - IUCN. 2017. IUCN Red List of Threatened Species. Version 2017.1. Retrieved August 24, 2017, from http://www.iucnredlist.org

Kats, L. B., \& Ferrer, R. P. 2003. Alien predators and amphibian declines: review of two decades of science and the transition to conservation. Diversity and Distributions, 9, 99-110. DOI: 10.1046/j.1472-4642.2003.00013.x

Kowarik, I. 2011. Novel urban ecosystems, biodiversity, and conservation. Environmental Pollution, 159(8), 1974-1983. DOI:10.1016/j.envpol.2011.02.022

Lever, C. 2003. Naturalized Reptiles and Amphibians of the World. Oxford University Press, p. 344.

Lowe, S., Browne, M., Boudjelas, S., de Poorter, M. 2000. 100 of the World's worst invasive alien species a selection from the global invasive species database. Auckland: the Invasive Species Specialist Group (ISSG) a specialist group of the Species Survival Commission (SSC) of the World Conservation Union (IUCN): p. 12.

Morais, A. R., Siqueira, M. N., Lemes, P., Maciel, N. M., Marco Jr, P., Brito, D. 2013. Unraveling the conservation status of Data Deficient species. Biological Conservation, 166, 98-102. DOI: $10.1016 /$ j.biocon.2013.06.010 
Morellato, L. P. C., \& Haddad, C. F. B. 2000. Introduction: the Brazilian Atlantic Forest. Biotropica, 32, 786-792. DOI: 10.1646/0006-3606(2000)032[0786:ITBAF]2.0.CO;2

Moura, M. R., Motta, A. P., Fernandes, V. D., Feio, R. N. 2012. Herpetofauna da Serra do Brigadeiro, um remanescente de Mata Atlântica em Minas Gerais, Sudeste do Brasil. Biota Neotropica, 12(1), 209-235. DOI: 10.1590/S167606032012000100017

Myers, N., Mittermeier, R. A., Mittermeier, C. G., Fonseca, G. A. B., Kent, J. 2000. Biodiversity hotspots for conservation priorities. Nature, 403, 853-858. DOI: 10.1038/35002501

Nascimento, L. B., Leite, F. S. F., Eterovick, P. C., Feio, R. N. 2009. Anfíbios. In: G. M. Drumond, C. S. Martins, M. B. Greco \& F Vieira (Eds.), Biota Minas - diagnostico do conhecimento sobre a biodiversidade do estado de Minas Gerais. pp. 223-248. Belo Horizonte: UFMG - Fundação Biodiversitas.

Neves, M. O., Pereira, E. A., Lima, L. M. C., Folly, H., Oliveira, E. F., Santana, D. J., Feio, R. N. 2017. Anurans of Serra Negra da Mantiqueira, Zona da Mata of Minas Gerais, Brazil: a priority area for biodiversity conservation. Herpetology Notes, 10, 297-311.

Pifano, D. S., Valente, A. S. M., Castro, R. M., Pivari, M. O. D., Salimena, F. R. G., Oliveira-Filho, A. T. 2007. Similaridade entre os hábitats da vegetação do morro do Imperador, Juiz de Fora, Minas Gerais, com base na composição da sua flora fanerogâmica. Rodriguésia, 58(04), 885-904.

Provete, D. B. 2015. Editorial: wherefore and whither a check list? The journal at the age of 10. Check List, 11(4), 1680.

Pyron, R. A., \& Wiens, J. J. 2013. Large-scale phylogenetic analyses reveal the causes of high tropical amphibian diversity. Proceedings of the Royal Society of London B, Biological Sciences, 280(1770), 20131622. DOI: 10.1098/ rspb.2013.1622

Ribeiro, M. C., Metzger, J. P., Martensen, A. C., Ponzoni, F. J., Hirota, M. M. 2009. The Brazilian Atlantic Forest: how much is left, and how is the remaining forest distributed? Implications for conservation. Biological Conservation, 142, 1141-1153. DOI: 10.1016/j.biocon.2009.02.021

Rosauer, D., Laffan, S. W., Crisp, M. D., Donnellan, S. C., Cook, L. G. 2009. Phylogenetic endemism: a new approach for identifying geographical concentrations of evolutionary history. Molecular Ecology, 18, 4061-4072. DOI: 10.1111/ j.1365-294X.2009.04311.x

Salles, R. D. O. L., Passos, N., Wogel, H., Bilate, M. 2012. New record and distribution extension of Hylodes lateristrigatus (Anura: Hylodidae) in Rio de Janeiro State, southeastern Brazil. Herpetology Notes, 5, 389-390.

Santana, D. J., Neves, M. O., Fonseca, E. M., Carvalho, R. M. H. 2012. A new species of Adelophryne (Anura: Eleutherodactylidae) from the Atlantic forest, southeastern Brazil. Salamandra, 48, 187-192.
Segalla, M. V., Caramaschi, U., Cruz, C. A. G., Grant, T., Haddad, C. F. B., Garcia, P. C. A., Berneck, B. V. M., \& Langone, J. A. 2016. Brazilian amphibians: list of species. Retrieved October 31, 2016, from http://www.sbherpetologia.org.br/images/ LISTAS/Lista_Anfibios2016.pdf.

Silva, J. M. C., Sousa, M. C., \& Castelletti, C. H. M. 2004. Areas of endemism for passerine birds in the Atlantic forest, South America. Global Ecology and Biogeography, 13, 85-92. DOI: 10.1111/j.1466-882X.2004.00077.x

Silva, E. T. D., Both, C., \& Filho, O. P. R. 2016. Food habits of invasive Bullfrogs and native Thin-toed frogs occurring in sympatry in southeastern Brazil. South American Journal of Herpetology, 11(1), 25-33. DOI: 10.2994/SAJH-D-16-00001.1

Silvano, D. L., \& Segalla, M. V. 2005. Conservação de Anfíbios no Brasil. Megadiversidade, 1(1), 79-86.

Silveira, L. E., Beisiegel, B. M., Curcio, F. F., Valdujo, P. H., Dixo, M., Verdade, V. K., Mattox, G. M. T., Cunningham, P. T. M. 2010. Para que servem os inventários de fauna? Estudos Avançados, 68, 173-207. DOI: 10.1590/S010340142010000100015

Siqueira, C. C., \& Rocha, C. F. D. 2013. Altitudinal gradients: concepts and implications on the biology, the distribution and conservation of Anurans. Oecologia Australis, 17(2), 282302. DOI: $10.4257 /$ oeco.2013.1702.09

SOSMA - Fundação SOS Mata Atlântica. 2017. Florestas. Retrieved August 25, 2017 from https://www.sosma.org.br

Souza-Campana, D. R., da Silva, O. G., Menino, L., Morini, M. S. D. C. 2016. Epigaeic ant (Hymenoptera: Formicidae) communities in urban parks located in Atlantic Forest biome. Check List, 12(5), 1967.

Thomé, M. T., Zamudio, K. R., Giovanelli, J. G. R., Haddad, C. F. B., Baldissera Jr., F. A. Alexandrino, J. 2010. Phylogeography of endemic toads and post-Pliocene persistence of the Brazilian Atlantic Forest. Molecular Phylogenetics and Evolution, 55(2010), 1018-1031. DOI: 10.1016/ j.ympev.2010.02.003

Vasconcelos, T. S., Prado, V. H. M, da Silva, F. R., Haddad, C. F. B. 2014. Biogeographic distribution patterns and their correlates in the diverse frog fauna of the Atlantic Forest hotspot. PLOS ONE 9(8), e104130. DOI: 10.1371/ journal.pone.0104130

Verdade, V. K., Valdujo, P. H., Carnaval, A. C. O. Q., Schiesari, L. C., Toledo, L. F., Mott, T., Andrade, G., Eterovick, P. C., Menin, M., Pimenta, B. V. S., Lisboa, C. S., Paula, D. C., Silvano, D. 2012. A leap further the Brazilian Amphibian Conservation Plan. Alutes - International Journal of Batrachology, 29, 28-43.

Vrcibradic, D., Oliveira, J. C., Pralon, E., Rocha, C. F. D. 2014. Amphibia, Anura, Hylodidae, Hylodes lateristrigatus (Baumann, 1912): filling distribution gap. Check List, 10(3), 677-678.

Submitted: 01 November 2016

Accepted: 01 October 2017

Associate Editors: Fábio Maffei and Ana C. Delciellos 


\section{APPENDIX}

Appendix 1. Voucher specimens: Ischnocnema juipoca - CAUFJF 892; Ischnocnema nasuta - CAUFJF 750, 1031; Ischnocnema verrucosa - CAUFJF 1231, 1232; Ischnocnema sp. (aff. guentheri) - CAUFJF 1513, 1515; Ischnocnema gr. lactea-CAUFJF 54; Ischnocnema gr. parva 1-CAUFJF 1567, 1568; Ischnocnema gr. parva 2-CAUFJF 991, 992; Rhinella gr. crucifer-CAUFJF 695, 696, 1077, 1097; Haddadus binotatus - CAUFJF 1200, 1201; Thoropa miliaris - CAUFJF 917, 1037; Zachaenus carvalhoi-CAUFJF 1220, 1221; Adelophryne meridionalis - CAUFJF 783, 784; Bokermannohyla gr. circumdata-CAUFJF 1125, 1206; Dendropsophus branneri-CAUFJF 1174, 1175; Dendropsophus decipiens - CAUFJF 1532, 1533; Dendropsophus elegans - CAUFJF 1529, 1530; Dendropsophus minutus - CAUFJF 1021, 1022; Hypsiboas albomarginatus - CAUFJF 1016, 1017; Hypsiboas albopunctatus - CAUFJF 311, 312; Hypsiboas faber-CAUFJF 1106 , 1139; Hypsiboas pardalis - CAUFJF 1156, 1205; Hypsiboas polytaenius - CAUFJF 1166, 1167; Hypsiboas semilineatus CAUFJF 1517, 1518; Phasmahyla cochranae-CAUFJF 791; Phyllomedusa burmeisteri-CAUFJF 1012, 1013; Scinax crospedospilus - CAUFJF 1572, 1573, 1574; Scinax eurydice-CAUFJF 1069, 1207; Scinax fuscovarius-CAUFJF 403, 608; Scinax hayii - CAUFJF 56, 57; Scinax luizotavioi-CAUFJF 1114, 1577; Scinax x-signatus - CAUFJF 623, 624; Scinax gr. catharinae - CAUFJF 891; Hylodes lateristrigatus - CAUFJF 907, 908; Adenomera marmorata - CAUFJF 1153, 1157; Leptodactylus furnarius - CAUFJF 122,1152; Leptodactylus fuscus - CAUFJF 1044, 1045; Leptodactylus labyrinthicus-CAUFJF 611, 1163; Leptodactylus latrans-CAUFJF 1172, 1173; Physalaemus cuvieri-CAUFJF 1183, 1512; Physalaemus signifer - CAUFJF 120; Chiasmocleis mantiqueira - CAUFJF 893, 1507; Elachistocleis cesarii CAUFJF 64; Myersiella microps - CAUFJF 933, 942; Odontophrynus americanus - CAUFJF 591; Proceratophrys boieiCAUFJF 1185, 1186; Lithobates catesbeianus - CAUFJF 256, 257. 